\title{
丛枝菌根对喜树幼苗生长和氮、磷吸收的影响
}

\author{
赵 昕 阎秀峰* \\ (东北林业大学生命科学学院, 哈尔滨 150040)
}

摘 要 喜树 (Camptotheca acuminata) 是我国特有的多年生亚热带落叶阔叶树种, 因其次生代谢产物喜树碱具有良 好的抗肿瘤活性而受到人们的广泛关注。该文通过温室盆栽接种试验，观察了 2 属 6 种丛枝菌根真菌即蜜色无梗 囊霉 ( Acaulospora mellea) 、光壁无梗囊霉 ( A. laevis)、木薯球囊霉 ( Glomus manihot)、地表球囊霉 ( G. versiforme)、幼套 球囊霉 $(G$. etunicatum $)$ 和透光球囊霉 ( $G$. diaphanum $)$ 对喜树幼苗生长和氮、磷养分吸收的影响。结果表明, 丛枝菌 根的形成对喜树幼苗的生长以及氮、磷营养的吸收均有影响。从生物量看, 除幼套球囊霉和光壁无梗囊霉侵染形 成的丛枝菌根喜树幼苗与无菌根幼苗 (CK) 差异不显著外, 其余菌根幼苗的生物量均明显大于无菌根幼苗, 透光球 囊霉和蜜色无梗囊霉菌根幼苗尤为突出, 分别达到无菌根幼苗的 1.9 和 1.4 倍。丛枝菌根的形成似乎不利于喜树 幼苗的氮素营养吸收, 并且主要体现在叶片的氮含量上。相反, 丛枝菌根形成总体上促进喜树幼苗对磷素营养的 吸收, 并且主要体现在根的磷含量上。与无菌根幼苗比, 所有菌根幼苗根的氮、磷分配比例增加, 而叶片的氮、磷分 配比例减少。

关键词 丛枝菌根 喜树幼苗 生物量 氮磷含量

\section{EFFECTS OF ARBUSCULAR MYCORRHIZAL FUNGI ON THE GROWTH AND ABSORPTION OF NITROGEN AND PHOSPHORUS IN CAMPTOTHECA ACUMINATA SEEDLINGS}

\author{
ZHAO Xin and YAN Xiu-Feng * \\ ( College of Life Sciences, Northeast Forestry University , Harbin 150040 , China)
}

\begin{abstract}
Background and Aims Camptotheca acuminata is a special Chinese tree that produces camptothecin (CPT) , a monoterpenoid indole alkaloid, which has gained great attention for its remarkable inhibitory activity against tumour cells.
\end{abstract}

Methods After 70-day growth period seedlings were inoculated with the arbuscular mycorrhizal (AM) fungi, Glomus manihot $(\mathrm{Gm}), G$. versiforme $(\mathrm{Gv}), G$. etunicatum ( $\mathrm{Ge}), G$. diaphanum ( $\mathrm{Gd})$, Acaulospora mellea $(\mathrm{Am})$ and $A$. laevis $(\mathrm{Al})$, respectively.

Key Results We investigated the effects of six species of AM fungi, belonging to two genera, on the growth , absorption of nitrogen and phosphorus in $C$. acuminata seedlings grown in the greenhouse. All inoculated seedlings were infected by six AM fungi and formed arbuscular mycorrhiza. The seedling growth and nitrogen and phosphorus absorption were affected by the formation of arbuscular mycorrhiza in $C$. acuminata. The biomass of mycorrhizal seedlings was significantly higher than that of non-mycorrhizal seedlings. For most mycorrhizal seedlings, the ratio of root to shoot was larger than that of the control. Nitrogen contents in $\mathrm{Gm}, \mathrm{Gv}$, $\mathrm{Ge}$ and $\mathrm{Al}$ were significantly lower than in the control. In contrast, phosphorus contents in plant of all mycorrhizal seedlings were higher than in non-mycorrhizal seedlings. Arbuscular mycorrhizal formation also changed the allocation of nitrogen and phosphorus in different organs of seedlings.

Conclusions These patterns suggest that the symbiotic association between $C$. acuminata roots and AM fungi effectively maintains nutrient homeostasis through changes in physiological properties , including nutrient uptake and allocation.

Key words Arbuscular mycorrhiza, Camptotheca acuminata seedlings, Biomass, Nitrogen and phosphorus contents

菌根是自然界中极为普遍和重要的共生现象， 
et al ，，2003）,80\%～90\%的被子植物都能形成丛枝 菌根 (Koide \& Schreiner, 1992)。丛枝菌根有利于植 物对养分的吸收 (Smith \& Read，1997)，从而改善植 物的生长状况 (Varma，1998; Mahendra et al. , $2001)$ 。许多研究表明，丛枝菌根能显著增加植物的 生物量，促进植物的生长(宋勇春等，2001; 冷平生 等, 2001)。张功等(2001)研究了不同 VA 菌根真菌 对马铃薯 (Solanum tuberosum) 生长的影响, 发现菌根 真菌显著提高了马铃薯的干重和产量, 并促进了马 铃薯对氮、磷营养的吸收。同样, 赵丽莉和王虹 (1998) 也发现接种 VA 菌根真菌能够显著促进小麦 ( Triticum aestivum) 的生长。

喜树 (Camptotheca acuminata) 是我国特有的多年 生亚热带落叶阔叶树种, 因其次生代谢产物喜树碱 具有良好的抗肿瘤活性而受到人们的广泛关注 (Yan et al . , 2003; 冯建灿等 ,2000)。对于喜树的生物学 特性 (席梦利和包少康, 1997 ; 李凤兰等，1998) 和 生长规律(姚建祥等，1997; 石柏林等，1999; 周国 模等, 2000 ; 张秋娟等, 2000) 等已有一些研究工 作,黄永芳等(2003)则以苏格兰球囊霉 (Glomus caledonium) 和地表球囊霉 ( $G$. versiforme, $\mathrm{Gv}$ ) 接种喜树 幼苗, 初步观察了丛枝菌根的形成及其对喜树幼苗 生长的影响。关于丛枝菌根对喜树幼苗生长、养分 吸收及生理代谢的影响尚缺乏深入研究。我们通过 温室盆栽接种实验, 探讨了 2 属 6 种丛枝菌根真菌 对喜树幼苗的接种效应以及幼苗次生代谢的响应， 并报告了丛枝菌根对喜树幼苗生长及氮、磷营养吸 收的影响。

\section{1 材料和方法}

\section{1 从枝菌根真菌}

无梗囊霉属: :蜜色无梗囊霉 (Acaulospora mellea， $\mathrm{Am})$ 和光壁无梗囊霉 $(A$. laevis, $\mathrm{Al})$; 球囊霉属 : 木 薯球囊霉 $(G$. manihot, $\mathrm{Gm})$ 、地表球囊霉、幼套球囊 霉 $(G$. etunicatum, $\mathrm{Ge})$ 和透光球囊霉 $(G . d i-$ aphanum, $\mathrm{Gd}$ )。蜜色无梗囊霉、光壁无梗囊霉和木 薯球囊霉由中国科学院南京土壤研究所林先贵研究 员惠赠, 地表球囊霉和幼套球囊霉由中国农业大学 李晓林教授惠赠, 透光球囊霉由北京市农林科学院 提供。

\section{2 喜树幼苗培养及接种处理}

2004 年 3 月,精选成熟饱满的喜树种子，以 $0.5 \%$ 的 $\mathrm{KMnO}_{4}$ 浸泡消毒 $1 \mathrm{~h}$, 然后用无菌水洗去 $\mathrm{KMnO}_{4}$ 播入 $121{ }^{\circ} \mathrm{C}$ 灭菌 $2 \mathrm{~h}$ 的河沙中，幼苗开始长
出侧根时移入口径 $20 \mathrm{~cm}$ 、深 $20 \mathrm{~cm}$ 的花盆中。盆中 基质为土壤与河沙的混合物 (体积比 $3: 1$, 过 $2 \mathrm{~mm}$ 筛, 混合后 $121{ }^{\circ} \mathrm{C}$ 灭菌 $2 \mathrm{~h}$ ), 有机质含量 $1.91 \%$,全 氮含量 $1.04 \mathrm{~g} \mathrm{~kg}^{-1}$, 速效磷含量 $11.72 \mathrm{mg} \mathrm{kg}^{-1}$, 速 效钾含量 $0.22 \mathrm{~g} \mathrm{~kg}^{-1}, \mathrm{pH}$ 值 6.23。

5 月末 , 选择长势一致的喜树幼苗分为 7 组 (每 组 10 盆)进行接种处理。其中 1 组作为对照, 不接 种任何 AM 真菌 (在花盆中加入等量灭菌处理的接 种剂和 $10 \mathrm{ml}$ 各菌种混合滤液, 以保证微生物区系 一致); 另外 6 组分别接种含有木薯球囊霉、地表球 囊霉、幼套球囊霉、透光球囊霉、蜜色无梗囊霉和光 壁无梗囊霉孢子的菌土。每盆接种剂量为 $30 \mathrm{~g}$, 菌 土均匀层播于土表下 $8 \mathrm{~cm}$ 的幼苗根部。

接种后的喜树幼苗置于温室中自然培养, 温室 为自然采光, 昼夜温度自然过渡 $\left(18 \sim 28{ }^{\circ} \mathrm{C}\right)$, 湿度 $60 \% \sim 70 \%$ 。3 个月后测定喜树幼苗的各项指标。

\section{3 菌根侵染率统计}

随机选取喜树鲜根 30 条, 剪成长约 $1.0 \mathrm{~cm}$ 的 根段，采用 Phillips 和 Hayman (1970) 的染色方法染 色、制片、镜检、参照盖京苹等 (2004) 的方法统计菌 根侵染率、根系的菌根侵染强度和侵染根段的菌根 侵染强度。

菌根侵染率 $(\mathrm{F}, \%)=($ 菌根侵染的根段数 $/$ 检 测的根段总数) $\times 100 \%$

根系的菌根侵染强度 $(M ， \%)=($ 侵染根长 $/$ 总 根长) $\times 100 \%$

侵染根段的菌根侵染强度 $(\mathrm{m}, \%)=($ 根系的菌 根侵染强度/菌根侵染率) $\times 100 \%$

\section{4 幼苗生长状况测定}

量取株高后将喜树幼苗按根、茎、叶分开,称量 叶片鲜重后于 $80{ }^{\circ} \mathrm{C}$ 烘干至恒重 称重并计算根冠比 (根干重/地上部干重)。10 株重复。

\section{5 幼苗全氮和全磷含量测定}

参照崔晓阳 (1998) 的方法, 采用自动凯氏法测 定幼苗的全氮含量, 采用硫酸-高氯酸酸溶-钼锑抗 比色法测定幼苗的全磷含量。

\section{以上数据用 SPSS 软件进行统计分析。}

\section{2 结果与分析}

\section{1 喜树幼苗的菌根形成情况}

接种 $\mathrm{Gm} 、 \mathrm{Gv} 、 \mathrm{Ge} 、 \mathrm{Gd} 、 \mathrm{Am}$ 和 $\mathrm{Al}$ 孢子菌土的喜树 幼苗 均不同程度地被侵染并形成了丛枝菌根，而未 接种的喜树幼苗无菌根真菌侵染, 未形成丛枝菌根。 实验所用球囊霉属的 4 种真菌 ( Gm、Gv、Ge、Gd) 的菌 
根侵染率较高，均在 $70 \%$ 以上;无梗囊霉属的 2 种 真菌 $(\mathrm{Am} 、 \mathrm{Al})$ 的菌根侵染率稍低, 但最低的 $\mathrm{Al}$ 也接 近 $50 \%$ 。

从根系的菌根侵染强度和侵染根段的菌根侵染 强度看 (表 1), 菌根真菌结构不仅在菌根化根系中 占有较大比例，而且在幼苗整个根系中所占的比例 也较大, 这表明接种的 6 种丛枝菌根真菌与喜树幼 苗形成的共生体系发育状况良好。

\section{2 喜树幼苗的生长差异}

接种 3 个月后，尽管形成菌根的喜树幼苗与未 形成菌根的喜树幼苗在植株高度上的差异并不显 著, 但多数菌根幼苗的株高都有高于对照 (无菌根幼 苗)的趋势。在生物量方面, 大部分菌根幼苗优于无
菌根幼苗, 而且差异显著, 其中 $\mathrm{Am}$ 和 $\mathrm{Gd}$ 菌根幼苗 的生物量分别达到无菌根幼苗的 1.9 和 1.4 倍。并 且, 菌根幼苗间的差异也很大 (表 2)。与无菌根幼 苗相比, 除 $\mathrm{Ge}$ 菌根幼苗外, 其余菌根幼苗根系生物 量均明显增加,而茎和叶片生物量增长相对较 弱, 只有 $\mathrm{Am}$ 和 $\mathrm{Gd}$ 菌根幼苗与无菌根幼苗差异显 著。

根冠比经常作为衡量植株生长状态特别是植株 对土壤水分、养分状态反应的一个指标。从本实验 结果看，丛枝菌根的形成对喜树幼苗地上与地下部 分生物量的总体分配产生了较大的影响, 多数菌根 幼苗具有较大的根冠比值, 其中 $\mathrm{Gv} 、 \mathrm{Am}$ 和 $\mathrm{Al}$ 菌根 幼苗尤为明显 (表 2)。

表 16 种丛枝菌根真菌的侵染情况

Table 1 Colonization status of Camptotheca acuminata inoculated with arbuscular mycorrhizal fungi among six species

\begin{tabular}{cccc}
\hline $\begin{array}{c}\text { 处理 } \\
\text { Treatment }\end{array}$ & $\begin{array}{c}\text { 菌根侵染率 }(\%) \\
\text { Mycorrhizal colonization rate }\end{array}$ & $\begin{array}{c}\text { 根系的菌根侵染强度 }(\%) \\
\text { Mycorrhizal colonization intensity of root }\end{array}$ & $\begin{array}{c}\text { Mycorrhizal colonization intensity of infected root fragment } \\
\text { 染根段的菌根侵染强度 }(\%)\end{array}$ \\
\hline $\mathrm{CK}$ & $0^{\mathrm{a}}$ & $0^{\mathrm{a}}$ & $0^{\mathrm{a}}$ \\
$\mathrm{Gm}$ & $83.18 \pm 8.75^{\mathrm{b}}$ & $56.22 \pm 5.87^{\mathrm{b}}$ & $67.47 \pm 6.77^{\mathrm{b}}$ \\
$\mathrm{Gv}$ & $84.54 \pm 9.03^{\mathrm{b}}$ & $53.30 \pm 5.37^{\mathrm{b}}$ & $63.96 \pm 6.59^{\mathrm{b}}$ \\
$\mathrm{Ge}$ & $88.54 \pm 9.03^{\mathrm{c}}$ & $33.61 \pm 3.31^{\mathrm{c}}$ & $40.33 \pm 4.03^{\mathrm{c}}$ \\
$\mathrm{Gd}$ & $74.15 \pm 8.12^{\mathrm{d}}$ & $41.36 \pm 4.06^{\mathrm{d}}$ & $49.63 \pm 5.13^{\mathrm{d}}$ \\
$\mathrm{Am}$ & $70.54 \pm 6.87^{\mathrm{d}}$ & $56.14 \pm 4.76^{\mathrm{b}}$ & $55.32 \pm 5.71^{\mathrm{e}}$ \\
$\mathrm{Al}$ & $49.01 \pm 5.81^{\mathrm{e}}$ & $26.72 \pm 2.34^{\mathrm{e}}$ & $32.04 \pm 2.95^{\mathrm{f}}$ \\
\hline
\end{tabular}

$\mathrm{CK}$ : 未接种丛枝菌根真菌 Non-arbuscular mycorrhizal inoculation $\mathrm{Gm} 、 \mathrm{Gv} 、 \mathrm{Ge} 、 \mathrm{Gd} 、 \mathrm{Am} 、 \mathrm{Al}$ : 分别接种木薯球囊霉、地表球囊霉、幼套球囊霉、透 光球囊霉、蜜色无梗囊霉、光壁无梗囊霉 Inoculation with Glomus manihot, G. versiforme, G. etunicatum, G. diaphanum, Acaulospora mellea and A. laevis, respectively

表 2 丛枝菌根对喜树幼苗生长的影响

Table 2 Effects of arbuscular mycorrhiza on the seedling growth of Camptotheca acuminata

\begin{tabular}{|c|c|c|c|c|c|c|}
\hline \multirow{2}{*}{$\begin{array}{c}\text { 处理 } \\
\text { Treatment }\end{array}$} & \multirow{2}{*}{$\begin{array}{c}\text { 株高 }(\mathrm{cm}) \\
\text { Height }\end{array}$} & \multicolumn{4}{|c|}{ 生物量 Biomass } & \multirow{2}{*}{$\begin{array}{c}\text { 根冠比 } \\
\text { Root/shoot ratio }\end{array}$} \\
\hline & & $\begin{array}{c}\text { 根系干重 }\left(\mathrm{g} \mathrm{plant}^{-1}\right) \\
\text { Root dry weight }\end{array}$ & $\begin{array}{c}\text { 茎干重 }\left(\mathrm{g} \mathrm{plant}^{-1}\right) \\
\text { Stem dry weight }\end{array}$ & $\begin{array}{c}\text { 叶干重 }\left(\mathrm{g} \mathrm{plant}^{-1}\right) \\
\text { Leaf dry weight }\end{array}$ & $\begin{array}{l}\text { 全株干重 }\left(\mathrm{g} \mathrm{plant}^{-1}\right) \\
\text { Whole plant dry weight }\end{array}$ & \\
\hline CK & $18.50^{\mathrm{a}}$ & $0.37^{\mathrm{a}}$ & $0.30^{\mathrm{a}}$ & $0.58^{\mathrm{a}}$ & $1.25^{\mathrm{a}}$ & $0.42^{\mathrm{ab}}$ \\
\hline $\mathrm{Gm}$ & $19.14^{\mathrm{a}}$ & $0.51^{\mathrm{b}}$ & $0.34^{\mathrm{a}}$ & $0.62^{\mathrm{a}}$ & $1.47^{\mathrm{b}}$ & $0.53^{\mathrm{b}}$ \\
\hline $\mathrm{Gv}$ & $16.80^{\mathrm{a}}$ & $0.64^{\mathrm{c}}$ & $0.29^{\mathrm{a}}$ & $0.57^{\mathrm{a}}$ & $1.50^{\mathrm{b}}$ & $0.75^{\mathrm{c}}$ \\
\hline $\mathrm{Ge}$ & $19.53^{\mathrm{a}}$ & $0.35^{\mathrm{a}}$ & $0.29^{\mathrm{a}}$ & $0.52^{\mathrm{a}}$ & $1.16^{\mathrm{a}}$ & $0.43^{\mathrm{ab}}$ \\
\hline Gd & $20.63^{\mathrm{a}}$ & $0.45^{\mathrm{b}}$ & $0.48^{\mathrm{b}}$ & $0.78^{\mathrm{b}}$ & $1.71^{\mathrm{c}}$ & $0.36^{\mathrm{a}}$ \\
\hline $\mathrm{Am}$ & $20.13^{\mathrm{a}}$ & $0.88^{\mathrm{d}}$ & $0.56^{c}$ & $0.96^{c}$ & $2.40^{\mathrm{d}}$ & $0.58^{\mathrm{bc}}$ \\
\hline $\mathrm{Al}$ & $18.27^{\mathrm{a}}$ & $0.48^{\mathrm{b}}$ & $0.32^{\mathrm{a}}$ & $0.48^{\mathrm{a}}$ & $1.29^{\mathrm{ab}}$ & $0.60^{\mathrm{bc}}$ \\
\hline
\end{tabular}

CK、Gm、Gv、Ge、Gd、Am、Al : 表 1 See Table 1 同一列数据中字母不同者表示差异显著 $(p<0.05)$ Data with different letters are significantly different $(p<0.05)$ in the same column

\section{3 喜树幼苗的氮、磷养分差异}

丛枝菌根的形成对喜树幼苗氮素营养的吸收有 一定的影响(图 1)。

从幼苗根的情况看,Am 菌根幼苗的氮含量显 著高于无菌根幼苗, 而其它菌根幼苗的氮含量均与 无菌根幼苗相近, 差异不显著。茎的情况则不同于
根，Gm、Gv、Gd、Am 菌根幼苗的氮含量与无菌根幼苗 差异不显著, 而 $\mathrm{Ge} 、 \mathrm{Al}$ 菌根幼苗的氮含量则显著低 于无菌根幼苗。叶片的情形又有变化, 氮含量显著 低于无菌根幼苗的有 $\mathrm{Gm} 、 \mathrm{Gv} 、 \mathrm{Ge}$ 和 $\mathrm{Am}$ 菌根幼苗, 而 $\mathrm{Gd}$ 和 $\mathrm{Al}$ 菌根幼苗与无菌根幼苗几无差异。从全 株的氮含量看，丛枝菌根的形成似乎不利于喜树幼 
苗的氮素营养吸收，除 Gd 和 Am 菌根幼苗与无菌根 幼苗差异不明显外，其余 4 种 $(\mathrm{Gm} 、 \mathrm{Gv} 、 \mathrm{Ge} 、 \mathrm{Al})$ 菌根 幼苗的全株氮含量均显著低于无菌根幼苗。
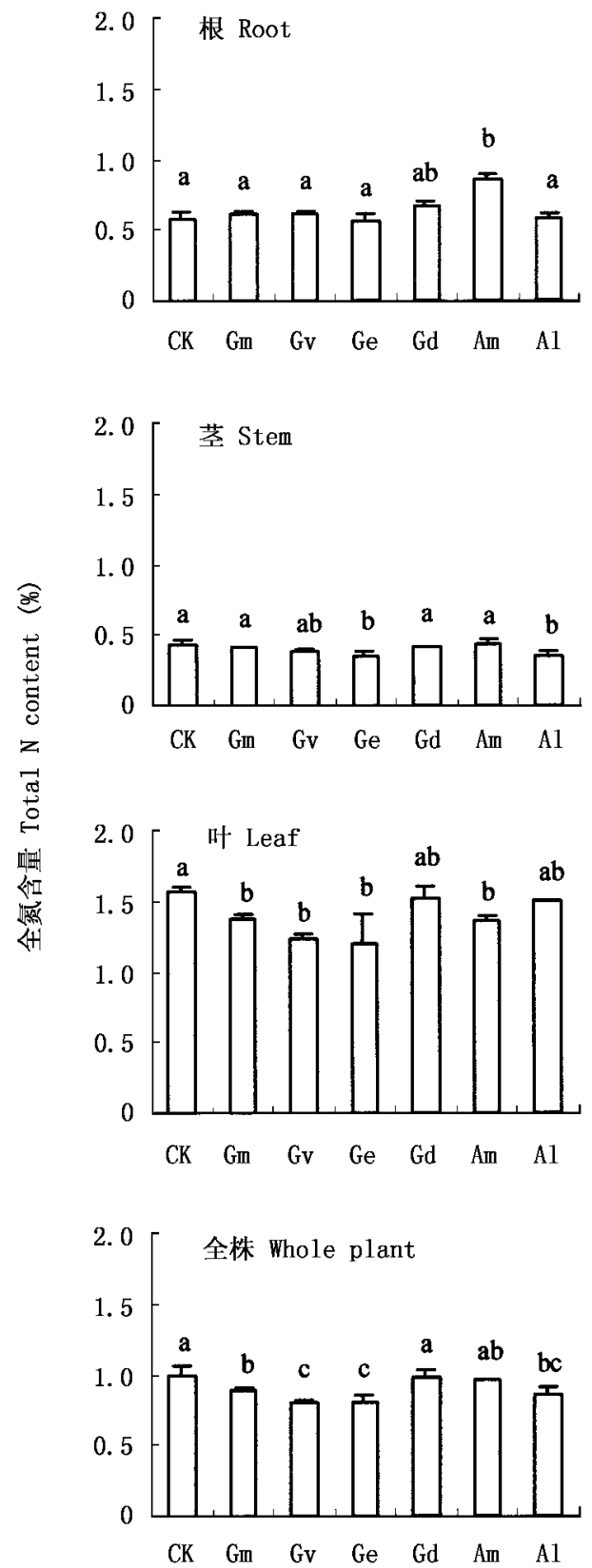

丛枝菌根的形成对喜树幼苗磷素营养的吸收也 有影响，但情形不同于氮素，总体上菌根的形成促进 了喜树幼苗对磷素营养的吸收(图 1)。

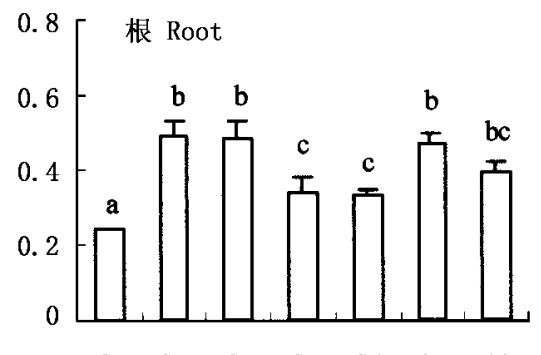

CK Gin Gv Ge Gd An $A 1$

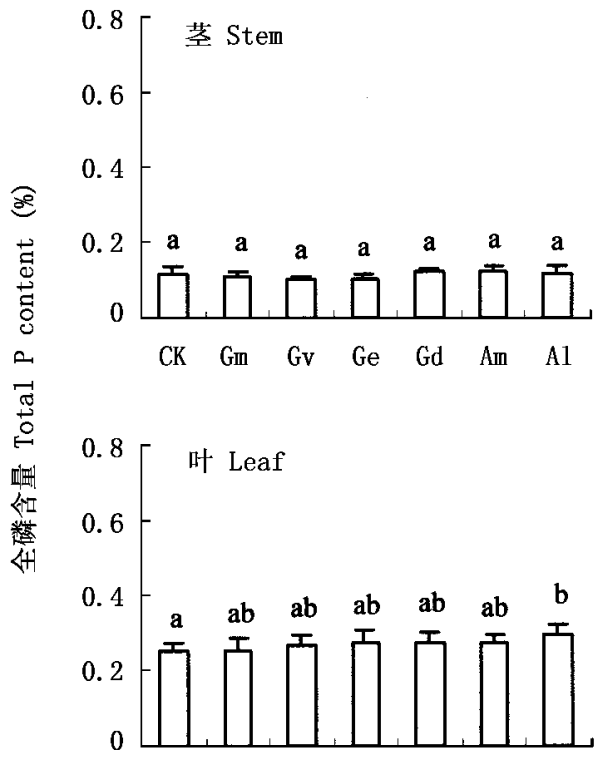

CK Gm Gv Ge Gd Am A1

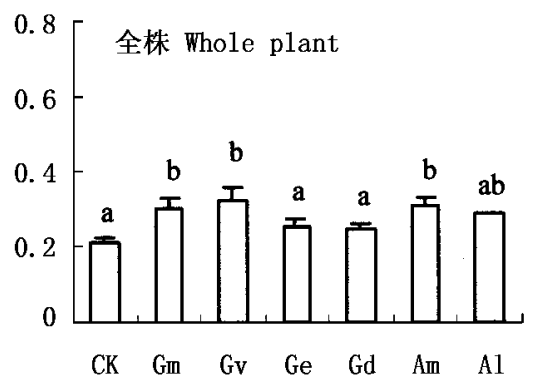

图 1 不同丛枝菌根喜树幼苗的氮、磷含量

Fig. $1 \mathrm{~N}$ and $\mathrm{P}$ contents of Camptotheca acuminata seedlings with different arbuscular mycorrhiza

$\mathrm{CK} 、 \mathrm{Gm} 、 \mathrm{Gv} 、 \mathrm{Ge} 、 \mathrm{Gd} 、 \mathrm{Am} 、 \mathrm{Al}$ :见表 1 See Table 1 图中具有不同字母的柱体间差异显著 $(p<0.05)$ The bars with different letters are significantly different $(p<0.05)$

菌根形成对喜树幼苗茎和叶片的磷含量影响不 大(只有 $\mathrm{Al}$ 菌根幼苗叶片的磷含量显著高于无菌根 幼苗) ,而对根的磷含量影响很大。试验的 6 种丛枝 菌根真菌侵染形成的喜树菌根幼苗, 根的磷含量均 显著高于无菌根幼苗，Gm、Gv、Ge、Gd、Am 和 $\mathrm{Al}$ 菌根
幼苗根的磷含量分别是无菌根幼苗的 2.0、2.0、1 .3、 1.4、1.9 和 1.6 倍。并且, 菌根幼苗之间的差异也十 分明显。从喜树幼苗全株的磷含量看, 所有菌根幼 苗都高于无菌根幼苗。不过 $\mathrm{Ge} 、 \mathrm{Gd} 、 \mathrm{Al}$ 菌根幼苗与 无菌根幼苗之间差异不显著, 而 Gv、Am、Gm 菌根幼 
苗则分别达到无菌根幼苗的 $1.5 、 1.4$ 和 1.4 倍, 差 异显著 $(p<0.05)$ 。

丛枝菌根的形成对喜树幼苗氮、磷养分吸收的 影响, 还体现在氮、磷在各器官中的分配差异 (图 2)。与无菌根幼苗相比, 所有菌根幼苗根的氮素分 配比例增加。其中，Gm、Gv、Am、 $\mathrm{Al}$ 菌根幼苗尤为明 显, 与无菌根幼苗之间差异显著 $(p<0.05)$ 。菌根幼 苗茎的氮素分配比例与无菌根幼苗相比变化不大, 而叶片的氮素分配比例则均低于无菌根幼苗，Gm、 $\mathrm{Gv} 、 \mathrm{Am} 、 \mathrm{Al}$ 菌根幼苗与无菌根幼苗之间的差异也达
到显著水平 $(p<0.05)$ 。

磷素的器官分配情况与氮素相似 (图 2)。菌根 幼苗根的磷素分配比例均高于无菌根幼苗，只有 $\mathrm{Gd}$ 菌根幼苗与无菌根幼苗之间差异不显著。同样, 叶 片的磷素分配比例也都低于无菌根幼苗，Gm、Gv、 $\mathrm{Am} 、 \mathrm{Al}$ 菌根幼苗与无菌根幼苗之间的差异达到了显 著水平 $(p<0.05)$ 。与氮素器官分配情况不同的是， 除 Gd 菌根幼苗茎的磷素分配比例略高于无菌根幼 苗外, 其余菌根幼苗茎的磷素分配比例均显著低于 无菌根幼苗 $(p<0.05)$ 。
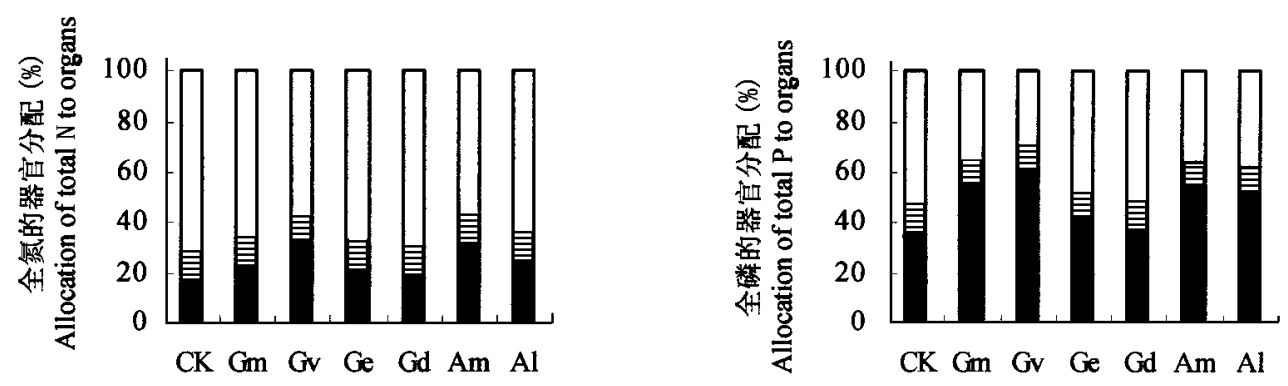

根 Root目茎 Stem $\square$ 叶 Leaf

图 2 不同丛枝菌根喜树幼苗中氮、磷的器官分配

Fig.2 Allocation of $\mathrm{N}$ and $\mathrm{P}$ to organs of Camptotheca acuminata seedlings with different arbuscular mycorrhiza CK、Gm、G、 Ge、Gd、Am、Al :见表 1 See Table 1

\section{3 结论与讨论}

丛枝菌根真菌与宿主植物的互利共生可以增强 植物从土壤中获取水分的能力 (毕银丽等, 2001) ,改 善植物根系对磷、铜、锌、镉等矿质元素及养分的吸 收(Hamel，1996; Dodd et al，2002)，从而促进植物 的生长 (Abu-Zeyad et al. , 1999 ; Ahiabor \& Hirata， 1994)。这方面的研究多数集中在草本植物如三叶 草( Trifolium pratense)、玉米 (Zea mays)、小麦等 (陶 红群等，1997; 宋勇春等，2001; 贺学礼和李生秀, 1999 ; 赵丽莉和王虹, 1998$)$, 以及农作物如黄瓜 ( Cucumis sativus)、甘薯 (Ipomoea batatas)、番茄 ( Lycopersicon esculentum) 等(王倡宪等，2003; 盖京苹等， 2004,2005 ; 朱红惠等，2005）,而对于木本植物尤其 是药用树木的研究较少。本试验的结果表明，丛枝 菌根的形成对喜树幼苗的生长以及氮、磷营养的吸 收均有影响。从生物量看, 除 $\mathrm{Ge}$ 和 $\mathrm{Al}$ 侵染形成的 丛枝菌根喜树幼苗与无菌根幼苗差异不显著外，其 余菌根幼苗的生物量均明显大于无菌根幼苗, Gd 和 $A m$ 菌根幼苗尤为突出。丛枝菌根的形成似乎不利
于喜树幼苗的氮素营养吸收, 并且主要体现在叶片 的氮含量上。相反，丛枝菌根形成总体上促进喜树 幼苗对磷素营养的吸收, 并且主要体现在根的磷含 量上。与无菌根幼苗比, 所有菌根幼苗根的氮、磷分 配比例增加，而叶片的氮、磷分配比例减少。

以往的工作有一些类似的研究结果, 如 Zandavalli 等 (2004) 用明球囊霉 (Glomus clarum) 接种窄 叶南洋杉 (Araucaria angustifolia) 发现形成菌根的窄 叶南洋杉生物量和含磷量显著增加而含氮量无明显 变化。同样, Plenchette 和 Duponnois (2005) 用根内球 囊霉 (G. intraradices) 接种大洋洲滨藜 (Atriplex nummularia) 时也发现, 虽然菌根的形成显著促进了大洋 洲滨僽的生长和对磷素营养的吸收, 却没有影响氮 素营养的吸收。盖京苹等 (2004) 也发现, 接种根内 球囊霉的甘薯, 根的磷分配比例加大, 而地上部磷的 分配比例减少。当然, 也有一些研究认为丛枝菌根 的形成能够促进宿主植物对氮素营养的吸收 (贺学 礼等, 1999 ; 王维华等, 2003)。同样也有一些研究 结果显示, 菌根的形成对氮、磷等元素在各器官中或 地上部与地下部的分配比例没有明显的影响 (陆文 
龙等，1994; 冯固等，2000)。

此外，不同菌根真菌侵染形成的丛枝菌根之间， 在对喜树幼苗生长以及氮、磷营养吸收的影响上也 有差异。而且, 从现有实验结果还看不出这种差异 与菌根真菌种类 (属、种) 的明确关系。

\section{参 考 文 献}

Abu-Zeyad R, Khan AG, Khoo C (1999). Occurrence of arbuscular mycorrhiza in Castanospermum australe A. Cunn. \& C. Fraser and effects on growth and production of castanospermine. Mycorrhiza, 9, $111-117$.

Ahiabor BD, Hirata H (1994). Characteristic responses of three tropical legumes to the inoculation of two species of VAM fungi in Andosol soils with different fertilizers. Mycorrhiza, 5, 63-70.

Bi YL (毕银丽), Ding BJ (丁保建), Li XL (李晓林) (2001). Effects of VA mycorrhiza on utilizing nutrient and water of winter wheat. Chinese Journal of Soil Science (土壤通报), 32, 99 101. (in Chinese with English abstract)

Cui XY (崔晓阳) (1998). Modern Experimental Analysis Technology for Forestry Soil (森林土壤现代实验分析技术). Northeast Forestry University Press, Harbin, 73 - 78, 95 - 99. (in Chinese)

Dodd JC, Dougall TA, Clapp JP (2002). The role of arbuscular mycorrhizal fungi in plant community establishment at samphire Hoe, Kent, UK - the reclamation platform created during the building of the Channel tunnel between France and the UK. Biodiversity and Conservation, 11, 39-58.

Feng G (冯固), Li XL (李晓林), Li SX (李生秀) (2000). Effect of AM fungi on water and nutrition status of cornplants under salt stress. Chinese Journal of Applied Ecology (应用生态学 报), 11, 595-598. (in Chinese with English abstract)

Feng JC (冯建灿), Zhang YJ (张玉洁), Tan YD (谭运德), Zhang WJ (张文杰) (2000). The development in research on Camptotheca acuminata and utilization of camptothecin. Scientia Silvae Sinicae (林业科学), 36 (5), $100-108$. (in Chinese with English abstract)

Gai JP (盖京苹), Feng G (冯固), Li XL (李晓林) (2004). The effect of AM fungi on the growth of sweet potato. Chinese Journal of Eco-Agriculture（中国生态农业学报)，12(1), 111 - 113. (in Chinese with English abstract)

Gai JP (盖京苹), Feng G (冯固), Li XL (李晓林) (2005).

Field distribution pattern and metabolic activity of AM fungi and their effects on Ipomoea batatas growth. Chinese Journal of Applied Ecology (应用生态学报)，16,147 - 150. (in Chinese with English abstract)

Hamel C (1996) . Prospects and problems pertaining to the management of arbuscular mycorrhizae in agriculture. Agriculture, Ecosystems and Environment, 60, 197 - 210.

He XL (贺学礼), Li SX (李生秀) (1999). Effect of VA mycorrhizal fungi on the growth and drought resistance of maize. Acta
Universitatis Agriculturalis Boreali-Occidentalis (西北农业大学 学报), 27(6), 49-53. (in Chinese with English abstract)

He XL (贺学礼), Zhao LL (赵丽莉), Li SX (李生秀) (1999). Effects of water stress and VA mycorrhizal fungi on the growth of mungbean. Acta Agriculturae Nucleatae Sinica (核农学 报), 14, 290-294. (in Chinese with English abstract)

Huang YF (黄永芳), Li HH (李海华), Chen HY (陈红跃), Li Y (李勇) (2003). Preliminary study on the mycorrhiza inoculation on the seedling of Camptotheca acuminata. Guangdong Forestry Science and Technology (广东林业科技), 19(1), 40 - 42. (in Chinese with English abstract)

Koide RT, Schreiner RP (1992) . Regulation of the vesicular-arbuscular mycorrhizal symbiosis. Annual Review of Plant Physiology and Plant Molecular Biology, 43, 557 - 581 .

Leng PS (冷平生), Su SC (苏淑钗), Li YH (李月华), Wang SS (王沙生), Jiang XN (蒋湘宁) (2001). Effects of fertilier and drought stress on growth as well as flavonol glycosides and terpene lactone content of Ginkgo biloba seedlings. Journal of Beijing Agriculture College (北京农学院学报), 16(1), 32 37. (in Chinese with English abstract)

Li FL (李凤兰), Cao HY (曹弘瑜), Li JQ (李俊清) (1998). Comparison on the anatomical structure of secondary xylem in stem between Davidiain volucrata and Camptotheca acuminata. Journal of Beijing Forestry University (北京林业大学学报), 20(1), 75 - 78. (in Chinese with English abstract)

Lu WL (陆文龙), Zheng HL (郑鹤龄), Pan J (潘洁), Wang DF (王德芳) (1994). Effect of VA mycorrhiza fungi on maize absorption of phosphorus and nitrogen nutrition under unsterilized conditions. Acta Agriculturae Boreali-Sinica (华北农学报), 9 (4), 94 - 97. (in Chinese with English abstract)

Mahendra R, Deepak A, Singh A (2001) . Positive growth responses of the medicinal plants Spilanthes calva and Withania somnifera to inoculation by Piriformospora indica in a field trial. Mycorrhiza, 11, $123-128$.

Phillips JM, Hayman DS (1970) . Improved procedures for clearing and attaining parasitic and vesicular-arbuscular mycorrhizal fungi for rapid assessment of infection. Transactions of the British Mycological Society, 55, $158-161$.

Plenchette C, Duponnois R (2005). Growth responses of the saltbush (Atriplex nummularia L. ) to inoculation with the arbuscular mycorrhizal fungus Glomus intraradices. Journal of Arid Environments, $61,535-540$.

Shi BL (石柏林), Zhou GM (周国模), Ying YQ (应叶青), Wu JS (吴家胜), Chu JM (储家水), Xu SY (许绍远) (1999). Height growth of Camptotheca acuminata yearlings from various provenances. Journal of Zhejiang Forestry College (浙江 林学院学报), 16, 353 - 357. (in Chinese with English abstract)

Smith SE, Read DJ (1997). Mycorrhizal Symbiosis 2nd edn. Academic Press Inc., San Diego, 605.

Song YC (宋勇春), Li XL (李晓林), Feng G (冯固) (2001). 
Effect of inoculated Glomus versiforme of utilization of organic phosphorus by red clover. Chinese Journal of Applied \& Environmental Biology (应用与环境生物学报), 7, 134 - 137. (in Chinese with English abstract)

Strack D, Fester T, Hause B, Schliemann W, Walter MH (2003). Arbuscular mycorrhiza: biological, chemical, and molecular aspects. Journal of Chemical Ecology, 29, 1955 - 1979.

Tao HQ（陶红群）, Li XL (李晓林), Zhang JL (张俊铃) (1997). Effect of VA-mycorrhizal infection on growth and nutrient uptake of red clover at different $\mathrm{Zn}$ supply levels. Chinese Journal of Applied \& Environmental Biology (应用与环境生物 学报), 3, 263-267. (in Chinese with English abstract)

Varma A (1998). Mycorrhizae, the friendly fungi: what we know, what should we know and how do we know? In: Varma A ed. Modern Laboratory Manual-Mycorrhizae. Springer, Berlin, Heidelberg, New York, 1-24.

Wang CX (王倡宪), Qin L (秦岭), Feng G (冯固), Li XL (李 晓林) (2003). Effects of three arbuscular mycorrhizal fungi on growth of cucumber seedlings. Journal of Agro-Environment Science (农业环境科学学报), 22, $301-303$. (in Chinese with English abstract)

Wang WH (王维华), Li M (李敏), Liu RJ (刘润进), Li XL (李晓林) (2003). Effects of arbuscular mycorrhizal fungi on some physiological index of Zingiber officinace Rosc. Journal of Laiyang Agricultural College (莱阳农学院学报)，20，175 177. (in Chinese with English abstract)

Xi ML (席梦利), Bao SK (包少康) (1997). Study on the transition from procambium to cambium in Camptotheca acuminata. Acta Botanica Boreali-Occidentalia Sinica (西北植物学报), 17 (5) , 83-87. (in Chinese with English abstract)

Yan XF, Wang Y, Yu T, Zhang YH, Dai SJ (2003). Variation in camptothecin content in Camptotheca acuminata leaves. Botanical Bulletin of Academia Sinica, 44, 99 - 105.
Yao JX (姚建祥), Qian YC (钱银才), Shen XL (沈湘林), Jiang XF (蒋小凡), Li ZQ (李志勤), Yu SS (余水生), Xu SY (许绍远), Ying YQ (应叶青) (1997). Superiority of Camptotheca acuminta seedlings. Journal of Zhejiang Forestry College (浙江林学院学报), 14, 134 - 141. (in Chinese with English abstract)

Zandavalli RB, Dillenburg LR, de Souza PV (2004). Growth responses of Araucaria angustifolia (Araucariaceae) to inoculation with the mycorrhizal fungus Glomus clarum. Applied Soil Ecolo$g y, 25,245-255$.

Zhang G (张功), Wang Q (旺庆), Zheng R (峥嵘), Wang RJ (王瑞君) (2001). Effect of different VA mycorrhizal fungi on the growth of potatoes. Acta Agriculturae Boreali-Sinica (华北农 学报), 16(4), 115-118. (in Chinese with English abstract)

Zhang QJ (张秋娟), Li SL (李淑玲), Feng JC (冯建灿), Wang XJ (王新建), Zheng L (郑蕾) (2000). The Camptotheca acuminata seedling's growth and changes of its physiological indexes under different $\mathrm{pH}$ stress. Journal of Henan Agricultural University (河南农业大学学报), 34, 193 - 195. (in Chinese with English abstract)

Zhao LL (赵丽莉), Wang H (王虹) (1998). The basal physiological study on promoting growth of wheat of VA mycorrhiza. Tritical Crops (麦类作物) , 18(1), 33-35. (in Chinese)

Zhou GM (周国模), Li XQ (李孝青), Chu JM (储家沝), Chen ZA (陈祖安), Xu SY (许绍远) (2000). Camptotheca acuminata: the law of growth and character correlation of young trees and sprouting branches. Journal of Zhejiang Forestry College (浙江林学院学报), 17, 355 - 359. (in Chinese with English abstract)

Zhu HH (朱红惠), Yao Q (姚青), Yang SZ (羊宋贞)（2005）。 The influence of different AM fungi inoculation on the vegetative growth and reproduction of tomato. China Vegetables (中国蔬 菜), (2), 9-11. (in Chinese with English abstract) 